\author{
Klaudia Cymanow-Sosin \\ Uniwersytet Papieski Jana Pawła II w Krakowie \\ ks. Michał Drożdż \\ Uniwersytet Papieski Jana Pawła II w Krakowie
}

\title{
ZAUFANIE W MEDIACH - ZAUFANiE DO MEDIóW. SPRAWOZDANIE Z KONFERENCJI
}

\begin{abstract}
XI Konferencja Naukowa Etyki Mediów Zaufanie w mediach - zaufanie do mediów. Trust in the media, 24-25 maja 2017 roku, Kraków, Instytut Dziennikarstwa i Komunikacji Społecznej Uniwersytetu Papieskiego Jana Pawła II w Krakowie.
\end{abstract}

Instytut Dziennikarstwa i Komunikacji Społecznej na Wydziale Nauk Społecznych Uniwersytetu Papieskiego Jana Pawła II w Krakowie już po raz kolejny był organizatorem ważnego wydarzenia w świecie specjalistów z nauk o mediach i dyscyplin pokrewnych. Na konferencji, która odbywała się w dniach 24-25 maja 2017 roku pod patronatem Polskiego Towarzystwa Komunikacji Społecznej, jak co roku spotkali się wybitni znawcy przestrzeni medialnej, by toczyć dyskusje o stanie badań nad etyką w komunikowaniu i mediach, a także zastanawiać się nad zagadnieniami aksjologicznymi w obrębie samych mediów.

W trosce o etyczność mediów zespół pracowników naukowych Instytutu Dziennikarstwa i Komunikacji Społecznej Uniwersytetu Papieskiego Jana Pawła II w Krakowie już od 11 lat Konferencje Etyki Mediów, którym przewodniczy ks. dr hab. Michał Drożdż, prof. UPJPII. W czasie tegorocznej XI Konferencji Naukowej Etyki Mediów Zaufanie $w$ mediach - zaufanie do mediów. Trust in the media, podejmowane były z różnych perspektyw medioznawczych kluczowe zagadnienia związane z zaufaniem w mediach i zaufaniem do mediów. Zaufanie jest zasadniczo darem osobowym, dlatego też w przestrzeni komunikowania medialnego nie można pominąć perspektywy osobowych relacji opartych na zaufaniu, czego wyrazem jest uznawanie dziennikarstwa jako zawodu zaufania publicznego. Zaufanie w mediach i zaufanie do mediów stanowią także wyznacznik jakości relacji społecznych i jakości mediów. Dlatego troszcząc się o poprawę 
i doskonalenie tej jakości, trzeba podnosić poziom społecznego zaufania w mediach i poprzez media.

Dwudniowa konferencja, nad którą patronat honorowy objęli JM ks. prof. dr hab. Wojciech Zyzak, rektor UPJPII, ks. dr hab. Antoni Świerczek, dziekan WNS UPJPII, a także wojewoda małopolski Józef Pilch i marszałek województwa małopolskiego Jacek Krupa, była okazją do prezentacji wyników własnych badań, prowadzenia szerokiej debaty, ale i - co także istotne w naszej dyscyplinie - integracji polskiego środowiska medioznawczego.

Konferencję rozpoczął dr hab. Michał Drożdż, prof. UPJPII, wskazując na doniosłe znaczenie wartości zaufania nie tylko w relacjach medialnych, ale we wszystkich relacjach społecznych. Podkreślił on zdecydowanie, że brak zaufania w relacjach społecznych i relacjach medialnych uniemożliwia życie godne człowieka. Niezwykle interesująco przedstawiały się obrady w trzech sesjach plenarnych. W pierwszej, której przewodniczył prof. dr hab. Kazimierz Wolny-Zmorzyński, dyskutowano o zaufaniu do mediów. W panelu wzięli udział: dr hab. Izabela Dobosz, prof. UPJPII, która wygłosiła referat na temat Zaufania do mediów w świetle reformy radiofonii i telewizji publicznej $w$ Polsce, a następnie prof. dr hab. Jerzy Jastrzębski z tegoż uniwersytetu, który pytał: Dlaczego nie możemy wierzyć mediom? Dlaczego musimy wierzyć mediom? Na temat mediów w społeczeństwie islandzkim oraz pojęcia zaufania i sceptycyzmu w nim mówiła dr hab. Lidia Pokrzycka z Uniwersytetu Marii Curie-Skłodowskiej w Lublinie. Z kolei o continuum od manipulacji do dyskredytacji z podtytułem: Prowokacje dziennikarskie a kwestie etyczne przypomniał prof. dr hab. Marek Sokołowski z Uniwersytetu Warmińsko-Mazurskiego w Olsztynie. Panel zakończyło wystąpienie prof. dr. hab. Tomasza Gobana-Klasa z Wyższej Szkoły Informatyki i Zarządzania w Rzeszowie, który ze znaną sobie swadą opowiedział zgromadzonym - w tym licznej rzeszy studentów - o dekompozycji sfery publicznej w erze nowych mediów.

Druga z sesji plenarnych, pod przewodnictwem dr hab. Izabeli Dobosz, prof. UPJPII, miała tytuł Zaufanie w mediach. O roli reportera i relacjach między prawdą i fikcją w reportażu pisanym mówił prof. dr hab. Kazimierz Wolny-Zmorzyński z Uniwersytetu Papieskiego Jana Pawła II w Krakowie, zadając prowokujące pytanie: Czy w ogóle można mieć zaufanie do reportera? Po nim wstąpiła dr hab. Monika Przybysz z Uniwersytetu Kardynała Stefana Wyszyńskiego w Warszawie, przedstawiając nowe zagadnienie z obszaru PR: Fact checking $w$ erze fake newsów jako wyzwanie dla public relations $w$ social mediach. Z kolei O pożytkach płynących z... nadużywania zaufania w kinie współczesnym mówił dr hab. Jacek Ostaszewski, prof. UJ, a po nim dr hab. Grażyna Osika z Politechniki Śląskiej wskazała na strategię konfirmacyjną jako kryterium zaufania. Jako ostatni w tym panelu wystąpił dr hab. Piotr Łukowski, prof. UŁ, rozważając ciekawe zjawisko, jakim są tzw. „kłamstwa minutowe” i zdiagnozował je jako nowe oblicze niektórych mediów.

Trzecia sesja plenarna (Zaufanie w komunikowaniu społecznym), której przewodniczyła dr hab. Katarzyna Pokorna-Ignatowicz, prof. KAFM (Krakowska Akademia im. Frycza Modrzewskiego) rozpoczęła się od wystąpienia dr. hab. Wojciecha Furmana, prof. URz i dotyczyła odpowiedzi na pytanie: Czy fake news szkodza zaufaniu do przekazów dziennikarskich? Z filozoficznej perspektywy do kwestii zaufania podeszła dr hab. Joanna Mysona Byrska, prof. UPJPII, która rozważała skutki 
zaufania konsumenta do mediów w świecie konsumpcji, zaś dr hab. Jacek H. Kołodziej z Uniwersytetu Jagiellońskiego poruszył tematykę medialnej nieufności. O populizmie medialnym w kontekście kryzysu zaufania w sferze publicznej mówiła dr hab. Maria Magoska z Uniwersytetu Papieskiego Jana Pawła II w Krakowie, a wystąpienia w panelu zakończył ks. dr hab. Zbigniew J. Waleszczuk (Katholische Universität Eichstätt-Ingolstadt, Germany), który rozważał zaufanie w czasach internetu w świetle nauczania społecznego św. Jana Pawła II.

Po każdym z paneli odbyła się bardzo twórcza dyskusja, w której głos zabierali nie tylko prelegenci, ale i osoby, które miały okazję wysłuchać tych ciekawych wywodów, będących inspiracją do stawiania sobie i innym niejednorodnie bardzo trudnych pytań.

Obok trzech sesji plenarnych podczas konferencji odbyło się aż 11 sesji tematycznych. Pierwszą (Zaufanie jako wartość - podstawy i konteksty) poprowadził prof. dr hab. Jerzy Jastrzębski. Drugiej, zatytułowanej Zaufanie w reklamie i do reklamy, przewodniczyła dr Klaudia Cymanow-Sosin (Uniwersytet Papieski Jana Pawła II w Krakowie). Trzecia sesja dotyczyła zaufania do dziennikarzy i do ich przekazów, a prowadził ją dr hab. Wojciech Furman, prof. URz. W następnej podejmowano temat kontekstów zaufania w mediach i wokół mediów, a przewodniczyła jej dr Katarzyna Drąg (Uniwersytet Papieski Jana Pawła II w Krakowie). W kolejnym dniu obrad, 25 maja 2017 roku, sesję Wartość zaufania poprowadził dr hab. Mariusz Wojewoda (Uniwersytet Śląski w Katowicach). Szósta, poranna sesja Zaufanie w cyfrowym świecie odbywała się pod przewodnictwem dr hab. Marty Bolińskiej (Uniwersytet Papieski Jana Pawła II w Krakowie). Kolejną Zaufanie w public relations poprowadził dr hab. Jacek $\mathrm{H}$. Kołodziej. Ósma sesja - Zaufanie w nowych mediach prowadzona była przez dr. hab. Krzysztofa Gurbę (Uniwersytet Papieski Jana Pawła II w Krakowie), dziewiąta: Zaufanie do mediów w kontekście społecznym przez dr hab. Marię Magoską, a dwie ostatnie: Uczyć się zaufania w mediach i do mediów przez dr hab. Joannę Mysonę Byrską, prof. UPJPII oraz Budować potencjał zaufania do mediów przez dr. Sławomira Soczyńskiego SDS z tegoż uniwersytetu. Konferencję zakończył przewodniczący ks. dr hab. Michał Drożdż, prof. UPJPII, pochylając się nad tematem odwagi i granic zaufania w relacjach medialnych. Dokonał on także ilościowego (wręcz statystycznego), a przede wszystkim jakościowego podsumowania tej konferencji, podziękował przybyłym za cenne inspiracje naukowe i dokonał uroczystego zakończenia konferencji w auli Biblioteki Uniwersytetu Papieskiego Jana Pawła II w Krakowie przy ul. Bobrzyńskiego 10.

Jak podkreślali uczestnicy, zarówno ogólne hasło tego cyklu, jak i szczegółowe tematy w poszczególnych latach, proponowane przez organizatorów, są wyjątkową zachętą do pochylenia się nad kluczowymi kwestiami etycznymi. W tym roku dominujące było pojęcie zaufania w mediach i do mediów. Te bowiem funkcjonują współcześnie w różnego typu uwarunkowaniach społeczno-ekonomicznych, w których elementy komercji i fałszywie rozumianej poprawności w coraz większym stopniu determinują ich charakter i jakość. Podstawowym uwarunkowaniem komunikacji medialnej jest jednak człowiek jako wolny i rozumny, osobowy podmiot. Media to ludzie, a tam, gdzie jest człowiek, który wybiera, myśli i działa, tam ujawnia się potrzeba relacji interpersonalnych opartych na wzajemnym zaufaniu. Brak zaufania w relacjach społecznych i relacjach medialnych uniemożliwia życie godne człowieka. 
Podczas dwudniowego spotkania nie zabrakło dyskusji na temat zaufania jako wartości relacji społecznych i relacji medialnych, zaufania w mediach jako miary ludzkiego oblicza mediów; rozważań na temat mediów godnych i „niegodnych” zaufania; przyczyn i konsekwencji utraty zaufania odbiorców mediów; dziennikarstwa jako zawodu zaufania publicznego czy zaufania do mediów jako miary ich jakości i wiarygodności. Rozmawiano także o potrzebie zaufania w debacie publicznej i komunikowaniu politycznym, trosce o odpowiedzialność mediów za budowanie społeczeństwa opartego na zaufaniu; zaufaniu w świecie wirtualnej anonimowości i internetowych zagrożeniach oraz nadużyciach zaufania. Istotnymi kwestiami były ponadto: zaufanie jako ochrona prywatności w mediach społecznościowych, zaufanie w komunikowaniu perswazyjnym - reklamie, marketingu, public relations i media relations oraz edukacja medialna w kontekście zaufania.

Przybyli zgodnie potwierdzili założenia organizatorów, iż rozważając tematykę zaufania w przestrzeni komunikowania medialnego, nie można pominąć perspektywy relacji opartych na zaufaniu, czego wyrazem jest uznawanie dziennikarstwa za zawód zaufania publicznego. Zaufanie w mediach i zaufanie do mediów stanowią także wyznacznik jakości relacji społecznych i jakości mediów. Dlatego troszcząc się o poprawę i doskonalenie tej jakości, warto zabiegać o podnoszenie poziomu społecznego zaufania w mediach i poprzez media.

Co ważne, twórczym owocem konferencji są publikacje wydawane przez Wydawnictwo Biblos w ramach serii Etyka Mediów. Dotychczas ukazało się kilkanaście pozycji, a po tegorocznej konferencji planowane jest wydanie kolejnych dwóch monografii tematycznych. 